\title{
Not for the squeamish: A new microfossil indicator for the presence of humans
}

\author{
Mike Macphail \\ Department of Archaeology and Natural History, Research School of Pacific and Asian Studies, \\ The Australian National University, Canberra, ACT \\ mike.macphail@anu.edu.au
}

\section{Mary Casey}

Casey and Lowe Pty Ltd, Marrickville, NSW

\section{Matthew Kelly}

Archaeological and Heritage Management Solutions, Annandale, NSW

\section{Introduction}

Considerable efforts have been made to find proxy indicators for humans at sites lacking direct archaeological evidence such as pottery, tools and the remains of built structures. Indirect evidence of human activity, such as charcoal and pollen records showing deforestation, continues to be equivocal (cf.Ellison 1994), although pollen of introduced crop and ornamental plants are an important exception (Macphail 1999; Macphail and Casey 2008; Prebble and Wilmshurst 2009). Buried seeds with gnaw marks of the introduced Pacific rat (Rattus exulans) provide equally reliable evidence for detecting initial human colonisation of islands in Remote Oceania (Wilmshurst and Higham 2004).

In this note, we describe and illustrate additional specimens of a microfossil species, Cloacasporites sydneyensis, which is strongly associated with that most basic of human activities, defecation. At present, the microfossil has only been recorded from historical archaeological sites in Sydney. Our twofold aim is to (i) alert the wider archaeological community to the existence of another proxy for humans, and (ii) thereby test whether the microfossil also occurs in archaeological sites elsewhere, in particular in non-European contexts. 


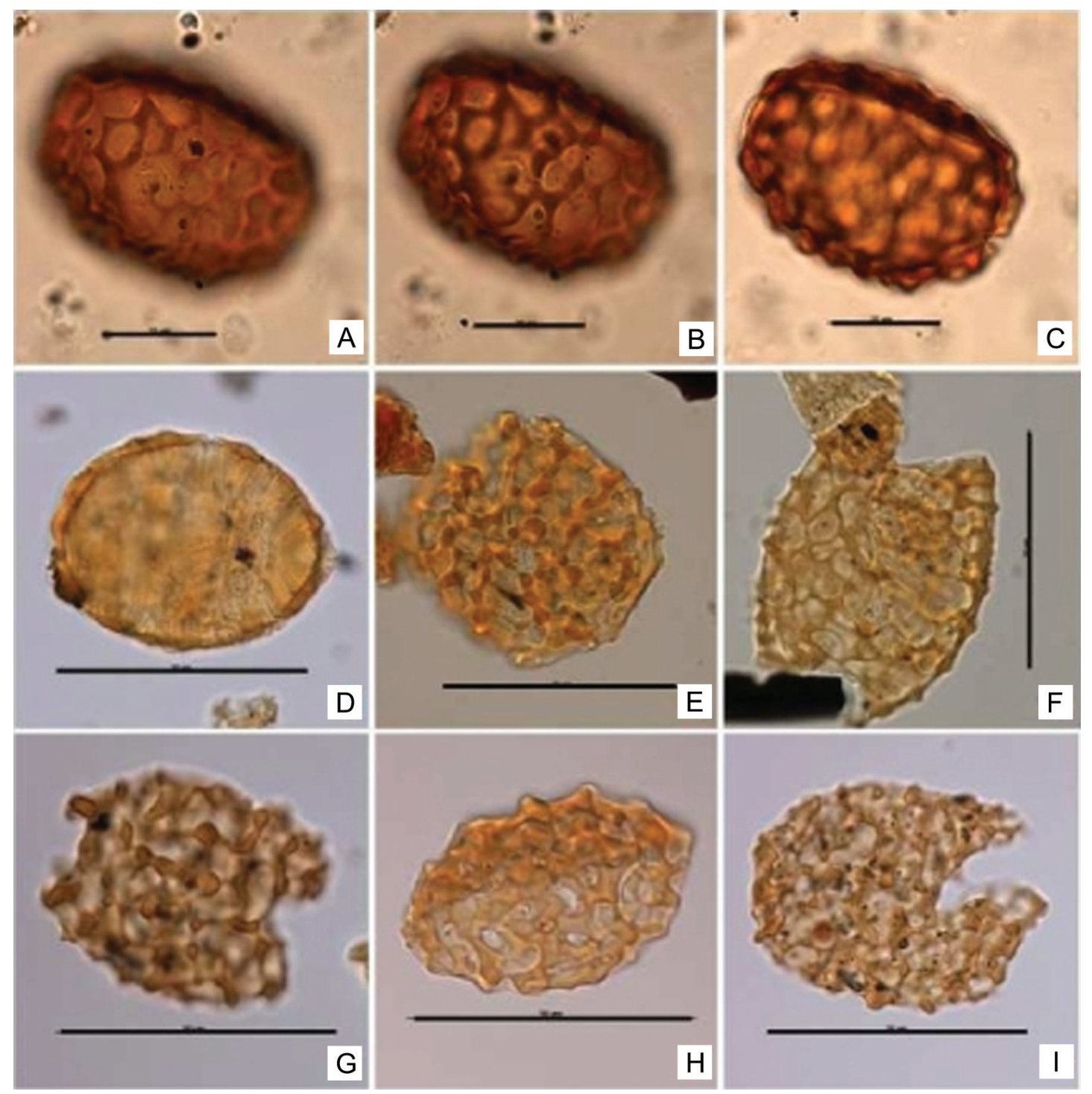

Figure 1. A-C. Upper fill in brick-lined cesspit (CTX F-1186), 66 Howard Street, Quadrant Development Site, Mountain Street and Broadway, Sydney (scale bar $=20 \mu \mathrm{m})$. D. Lower fill in wood-lined cesspit (CTX 8037), Darling Walk Development Site, Darling Harbour (scale bar = $50 \mu \mathrm{m})$. E-F. Fill in sandstone cesspit fill (CTX 8737), House 9, Darling Walk Development Site, Darling Harbour (scale bar = $50 \mu \mathrm{m})$. G-H. Mud mortar (CTX 8.020), Development Site at 185-193 Gloucester Street, the Rocks $($ scale bar $=50 \mu \mathrm{m})$. I. Mud mortar $($ CTX 8.012), Development Site at 185-193 Gloucester Street, the Rocks (scale bar $=50$ $\mu \mathrm{m})$.

\section{Cloacasporites sydneyensis (Macphail and Casey 2008)}

\section{Description:}

Monad, quasi-isopolar, subspherical to ellipsoidal; aperture if any obscured; laterally biconvex to concavo-convex, amb elliptical to subcircular; wall not stratified c. 0.8-4 $\mu \mathrm{m}$ thick; reticulate-rugulate, sculptural elements varying in width and thickness, c. 1-8 $\mu \mathrm{m}$ thick, weakly aligned longitudinally, coalescing to enclose subcircular to subangular lumina up to $16 \mu \mathrm{m}$ in maximum diameter, or breaking down into irregular rugulae and verrucae; 52 (71) $84 \mu \mathrm{m} \times 30$ (44) $56 \mu \mathrm{m}$ (20 specimens measured).

\section{Type specimens:}

Geoscience Australia CPC 3987 (Holotype) and 39788-39789 (Paratypes). 


\section{Derivation of Name:}

From Sydney, the capital city of New South Wales, where the microfossil was first recorded.

\section{Affinity:}

Unknown; presumed to be the egg case of an unidentified animal parasite.

\section{Discussion}

As well as fossil spores, pollen and algal cysts, most sedimentary deposits preserve numerous microfossils whose source(s) remain unknown (see Van Geel 2001:206). Nevertheless, some of these are useful for interpreting the past because of their strong empirical link with a particular depositional environment or archaeological context. Cloacasporites sydneyensis is an example of the latter.

This microfossil has been recorded in low to trace numbers at eight historical archaeological sites in Sydney (references in Macphail and Casey 2008).In almost all instances, the archaeological contexts are cesspits (Figure $1 \mathrm{~A}-\mathrm{C}$ ), drains used for the disposal of human sewage or other structures that are likely to have been contaminated with sewage. The latter include sediment infilling a well in the yard of a demolished terrace house near Wentworth Park - an area which is recorded as being flooded by sewage backing up along Blackwattle Creek during storms and high-tide surges into Blackwattle Bay during the late 19th century.

The specimens illustrated in Figure 1, D-F reinforce the association of Cloacasporites sydneyensis with Europeans, since these specimens were preserved in cesspits attached to demolished 19th century terrace houses on the Darling Walk Development Site, Darling Harbour (Casey \& Lowe 2009; M.K. Macphail unpubl. data). The specimens illustrated in Figure 1, G-I extend the record of the microfossils even closer to the site of the first European settlement in Australia, since these specimens were preserved in mud mortar used in the foundations of a ca. 1840 building at 185-193 Gloucester Street, the Rocks (Archaeological \& Heritage Management Solutions 2007; M.K. Macphail unpubl. data). Pollen of aquatic herbs and native shrubs occurs in the same samples and the combined data hint at sewage-pollution of the source of the water used to make the mud mortar, presumably the Tank Stream which had become one of Sydney's 'main sewers' by 1835 (de Vries-Evans 1987).

As noted by Macphail and Casey (2008), Cloacasporites sydneyensis is highly unlikely to be of plant origin, but the source remains unknown. The microfossil is not present in every cess-fill, including some that preserve pollen of cereal and other edible plants eaten by the colonial inhabitants, e.g. the cesspit attached to the demolished 1830s Wool Pack Inn at Old Marulan on the Southern Tablelands south of Sydney (Macphail 2008). This indicates the microfossil is less likely to be the egg case of flies, e.g. the blowfly (Calliphoridae species), or other insects attracted to human faeces. Accordingly, we have proposed it is the egg case of a parasite living in the human gut or that the host was present in/on one of the many animals eaten by Europeans during the colonial period. Time will tell whether Cloacasporites sydneyensis, like Rattus exulans, was one of many human commensals inadvertently introduced into the southwest Pacific region.

\section{References}

Archaeological \& Heritage Management Solutions Pty Ltd 2007. 185-193 Gloucester Street, The Rocks, NSW. A research design and excavation methodology for proposed historical archaeological excavation at the site. Report to Stamford Windsor Ltd. 
Casey \& Lowe Pty Ltd. 2009. Non-Indigenous Archaeological Assessment, Darling Walk, Darling Harbour. Report to Lend Lease Development.

De Vries-Evans, S. 1987. Historic Sydney as Seen by its Early Artists. Sydney: Angus and Robertson.

Ellison, J. 1994. Paleo-lake and swamp stratigraphic records of Holocene vegetation and sealevel changes. Mangaia, Cook Islands. Pacific Science 48:1-15.

Macphail, M.K. 1999. A hidden cultural landscape: Colonial Sydney's plant microfossil record. Australasian Historical Archaeology 17:79-115.

Macphail, M.K. 2008. Pollen analysis of soil samples from Old Marulan, Southern Tablelands, NSW. Report to Banksia Heritage \& Archaeology Pty Ltd.

Macphail, M.K. and Casey, M. 2008. News from the Interior: what can we tell from plant microfossils preserved on historical archaeological sites in colonial Parramatta. Australasian Historical Archaeology 26:45-69.

Prebble, M. and Wilmhurst, J. 2009. Detecting the initial impact of humans and introduced species on island environments in Remote Oceania using palaeoecology. Biological Invasions 11:1529-1556.

Van Geel, B. 2001. Non-pollen palynomorphs. In: Smol, J.P., Birks, H.J.B. and Last, W.M. (eds), Tracking Environmental Change Using Lake Sediments; Volume 3: Terrestrial, algal and silicaceous indicators, pp. 99-119. Dordrecht, Kluwer.

Wilmshurst, J.M. and Higham, T.F.G. 2004. Using rat-gnawed seeds to independently date the arrival of Pacific rats and humans in New Zealand. The Holocene 14:801-806. 